\title{
ISLAMIC WORLDVIEW DAN LAHIRNYA TRADISI ILMIAH DI INSTITUSI PENDIDIKAN ISLAM
}

\author{
Sarjuni 1) * \\ ${ }^{1}$ Program Studi Pendidikan Agama Islam, Fakultas Agama Islam \\ Universitas Islam Sultan Agung, Semarang \\ *E-mail: alfahanin@gmail.com
}

\begin{abstract}
This article seeks to describe that Islam is not just a religion that pays attention to issues of credo and ritual, but it is also a worldview that brings a change for Muslims. As an Islamic way of life, it has an integrated view of physical and non-physical realities. The verses of the Koran are seminal concepts that project an Islamic view of the universe and life which are referred to as Islamic natural views. It has a different view from the views of other religions and civilizations. Conceptually, Islam as a worldview is closely related to all human activities as social, intellectual and religious beings. As a system of belief, thought, and values, it has the power to change the conditions of civilization. So that in history, its presence has been able to generate scientific traditions through the earliest educational institutions known as Madrasas as-Suffah. From this Madrasa ash-Suffah, ashab ash-suffah (scientific community) developed, This scientific community is needed for the emergence of scientific traditions. The existence of this scientific tradition which later generate to major scholars in the fields of Kalam Science, Tafsir, Hadith, Fiqh, Sufism, etc., which in subsequent developments were able to give birth to polymath Muslim scientists, namely scientists who have expertise in various fields of science at once.
\end{abstract}

Keywords: Islamic Worldview, Scientific Traditions, Science

\begin{abstract}
Abstrak
Artikel ini berusaha untuk mendeskripsikan bahwa Islam bukan hanya sekedar agama yang menaruh perhatian pada masalah-masalah kredo dan ritual, akan tetapi ia juga sebagai pandangan hidup (worldview) yang menjadi motor penggerak perubahan bagi muslim. Sebagai pandangan hidup Islam ia memiliki pandangan terhadap realitas fisik dan non fisik secara integral. Ayat-ayat al-Qur'an adalah konsep seminal yang memproyeksikan pandangan Islam tentang alam semesta dan kehidupan yang disebut sebagai pandangan alam Islam. Ia memiliki pandangan yang berbeda dengan pandangan agama dan peradaban lain. Islam sebagai worldview berkaitan erat secara konseptual dengan segala aktivitas manusia sebagai makhluk sosial, intelektual dan religius. Sebagai sebuah sistem kepercayaan, pemikiran, tata pikir, dan tata nilai, ia memiliki kekuatan untuk mengubah kondisi peradaban. Sehingga dalam sejarah, kehadirannya telah mampu melahirkan tradisi ilmiah melalui institusi pendidikan yang paling awal yang dikenal dengan Madrasah ash-suffah. Dari madrasah ash-Suffah ini tumbuh dan berkembang ashab ash-suffah (komunitas ilmiah), Komunitas ilmiah ini diperlukan untuk munculnya tradisi ilmiah. Keberadaan tradisi ilmiah ini yang kemudian melahirkan ulamaulama besar dalam bidang Ilmu Kalam, Tafsir, Hadis, Fiqih, Tasawuf, dll, yang pada perkembangan selanjutnya mampu melahirkan ilmuwan muslim polymath, yakni ilmuwanilmuwan yang memiliki kepakaran di berbagai bidang ilmu sekaligus.
\end{abstract}

Kata Kunci: Islamic Worldview, Tradisi Ilmiah, Ilmu 


\section{PENDAHULUAN}

Sains sebagai hasil aktivitas manusia pada dasarnya harus memanifestasikan karakteristik manusia sebagai fondasi sosial dan epistemologisnya. Demikian juga dengan konsep sains dalam Islam. Tanpa memahami dua landasan keilmuan ini, tidak akan pernah dapat dijelaskan bagaimana tradisi ilmiah muncul dalam Islam. Tradisi ilmiah sejatinya merupakan landasan dimana ilmu pengetahuan dikembangkan dalam suatu peradaban atau masyarakat.

Akan tetapi dalam hal ini, kita akan selalu dihadapkan dengan lingkaran setan. Yakni terkait dengan mana yang lebih dulu antara sains dan kegiatan ilmiah. Hal ini karena sebelum adanya sains dalam peradaban Islam, tidak ada aktivitas pembelajaran yang dapat dikategorikan sebagai kegiatan ilmiah. Hal ini terjadi, karena tradisi pembelajaran atau tradisi intelektual apapun dapat dikatakan sebagai 'ilmiah' setelah adanya sains. Tradisi ilmiah diperlukan untuk mengembangkan sains, akan tetapi pada gilirannya sains diperlukan untuk menghasilkan tradisi ilmiah.

Dalam mata rantai sejarah pendidikan Islam, aktivitas ilmiah dapat ditemukan pada apa yang dikenal sebagai komunitas ilmiah atau ulama. Pengetahuan yang muncul dari komunitas tersebut sangat dirasakan manfaatnya oleh masyarakat. Ketika kesadaraan ini muncul di benak para cendekiawan yang terlibat dalam komunitas tersebut, mereka menyadari bahwa masalah pembelajaran yang mereka selidiki merupakan disiplin khusus, yang kemudian diberi nama tertentu yang menunjuk pada ilmu tertentu, misalnya ilmu kalam, ilmu fiqih, dan lain-lain. Kesadaran ini sering disebut dengan 'kesadaran ilmiah'.

Apabila kesadaran ilmiah masuk ke dalam pikiran secara alami, maka hal tersebut tidak bisa konvensional. Tetapi semua tradisi hampir pasti konvensional; karenanya, jika ada tradisi ilmiah, maka dapat disimpulkan bahwa sains sekaligus konvensional dan universal. Aspek konvensional muncul dari cara dan perilaku yang diadopsi oleh komunitas ilmiah, dan aspek universal muncul dari karakter epistemologis pikiran manusia. Dengan demikian, dapat dipahami bahwa ilmu pengetahuan muncul melalui proses yang disebut dengan 'proses ilmiah'. Menurut Alparslan Acikgene proses ilmiah dapat dibedakan mejadi tiga tahap:

1. The stage of problem, where secattered and discrete studies of various problems are cariet out for a period of time (tahap masalah, dimana studi yang tersebar dan terpisah dari berbagai masalah dilakukan untuk jangka waktu tertentu). 
2. The stage of disciplinary tradition, where a tradition arises as a result of conventional consensus among the scholars; general subject matter anda method are determined (tahap tradisi disiplin, dimana sebuah tradisi muncul sebagai hasil dari konsensus konvensional diantara para sarjana; materi dan metode umum ditentukan).

3. The stage of naming this scientific enterprise (tahap penamaan institusi ilmiah).

Worldview Islam yang muncul dari wahyu sangat relevan untuk tumbuh dan berkembangnya ilmu pengetahuan. Worldview inilah yang membimbing kemajuan ilmiah sejak awal perembangan Islam hingga era keemasan Peradaban Islam. Harus ada beberapa kondisi di tingkat sosial dengan semua aspeknya sebagai prasyarat kebangkitan pendidikan dalam masyarakat karena kondisi ini yang akan memunculkan pembelajaran dalam konteks sosial dan budaya yang sering disebut degan "penyebab kontekstual" lahirnya ilmu pengetahuan. Penyebab konstektual ini berperan sebagai kekuatan dinamis yang mengarah pada tradisi pembelajaran dan intelektualisme pra-ilmiah, dan ketika masyarakat mampu memberikan beberapa landasan yang sesuai untuk pengembangan worldview, maka ia berfungsi sebagai landasan konseptual bagi munculnya sains.

Babak Ayazifar, seorang staff pengajar di departemen Electrical Engineering and Computer Science, menyatakan pendapatnya bahwa: Islam is a religion of balance. Physical, sensory perception is not our sole endowment. Self-reflection, looking internally at our own spirit and soul, is another integral menas of acquiring knowledge and arriving at the real. (Islam adalah agama yang seimbang. Persepsi fisik dan indera bukanlah satu-satunya anugerah kita. Refleksi diri, melihat secara internal pada roh dan jiwa kita sendiri, adalah cara integral lainnya untuk memperoleh pengetahuan yang riil).

Munculnya kegiatan ilmiah disebabkan oleh dua hal, yakni; pertama, disebabkan oleh adanya penyebab konstektual nukleus (semua sebab konstektual yang melahirkan jenis-jenis kegiatan ilmiah). Kedua, disebabkan adanya penyebab konstektual marginal (elemen periferal lain yang mendukung munculnya tradisi ilmiah). Ada dua fenomena yang sesuai dengan penyebab konstektual neklus: yang pertama adalah dinamika moral; dan yang kedua adalah dinamisme intelektual.

Dinamika moral dan intelektual dapat terjadi sebagai fenomena sosial. Keresahan masyarakat yang disebabkan oleh kemerosotan moral dalam masyarakat tertentu menunjukkan perjuangan dua golongan manusia, yakni golongan yang sensitif secara moral dan golongan yang egois. Massa tetap sebagai kelas menengah diantara 
keduanya. Ketika perjuanagan terjadi, meskipun hanya antara yang peka secara moral dan yang egois, itu segera diteruskan ke massa, yang menjadi medan pertempuran kekuatan baik dan jahat. Beberapa massa dengan demikian dimenangkan ke sisi moral, dan yang lain ke depan yang egois. Tidak ada masyarakat manusia dimana perjuangan ini sebagai sunatullah tidak dapat ditemukan dalam satu bentuk atau lainnya.

Ketika orang-orang yang peka secara moral memiliki kekuatan, dinamisme, dan energi yang cukup, mereka dipihak yang menang dan dengan demikian menghasilkan dinamisme intelektual dan sosial. Ketika perjuangan moral antara kedua kelompok berlanjut dengan kemenangan golongan moral (karena perjuangan ini berakhir dengan kemenangan, tetapi selalu berlanjut dalam bentuk yang berbeda selama masyarakat ada), individu-individu yang secara moral sensitif baik menghasilkan intelektual atau diri mereka sendiri sebagai cndekiawan yang merumuskan gagasan, doktrin dan sistem asli dengan memperkenalkan definisi baru dan segar dari konsepkonsep kunci yang bermoral dan intelektual atau sebaliknya. Dengan cara ini pertukaran ide dan pandangan alternatif yang hidup muncul dalam masyarakat; sebuah fenomena yang diperlukan untuk menghasilkan dinamisme intelektual.

Perjuangan moral, pada dasarnya merupakan manifestasi pertarungan antara yang baik dan yang jahat di dalam kehidupan masyarakat. Hal ini dapat secara langsung menyebabkan timbulnya dinamika sosial, atau bisa jadi dinamisme intelektual terlebih dahulu, yang kemudian menghasilkan dinamisme sosial. Oleh karena itu, walaupun dalam beberapa kasus dinamisme sosial mungkin mendahului dinamika intelektual, itu tidak berarti bahwa dinamisme sosial adalah penyebab konstektual. Oleh karena itu, ini masih merupakan kontekstual sekunder terkait dengan sikap dan kegiatan tersebut. Untuk aktivitas tersebut adalah yang bersifat kognitif, yaitu, ilmu pengetahuan. Tetapi dinamisme sosial inilah yang biasanya mengarah pada aktivitas keseluruhan dalam masyarakat, yang disebut sebagai 'dinamisme institusional', yang memang banyak, tetapi kita dapat menyebutkan tertutama tiga untuk menunjukkan seignifikansinya dalam kemunculan ilmu pengetahuan dan kemajuan ilmiah. : dinamika pendidikan , politik dan ekonomi. Masyarakat secara keseluruhan memasuki proses pembentukan kembali lembaganya, sesuai dengan worldview yang dibangun dan konsep-konsep fundamental yang dikembangkan di dalamnya. 


\section{HASIL PENELITIAN DAN PEMBAHASAN}

\section{A. Makna dan Urgensi Islamic Worldview}

Worldview pada dasarnya merupakan suatu konsep yang dapat digunakan untuk menggambarkan cara pandang manusia secara umum tanpa melihat bangsa atau agama. Menurut Ninian Smart (n.d,: 1-2) worldview adalah kepercayaan, perasaan dan apa-apa yang terdapat dalam pikiran orang yang berfungsi sebagai motor bagi keberlangsungan dan perubahan sosial dan moral." Hampir serupa dengan Smart, Wall (2001:532) mengemukakan bahwa worldview adalah sistem kepercayaan dasar yang integral tentang hakekat diri kita, realitas, dan tetang makna eksistensi (unintegreted system of basic beliefs about the nature of yourself, reality, and the meaning of existence).

Lebih luas dari kedua definisi di atas Alparslan (1996:1-2)) mengartikan worldview sebagai asas bagi setiap perilaku manusia, termasuk aktivitas-aktivitas ilmiah dan teknologi. Setiap aktivitas manusia akhirnya dapat dilacak pada pandangan hidupnya, dan dalam pengertian itu maka aktivitas manusia dapat direduksi menjadi pandangan hidup. (the fondation of all human conduct, including scientific and technological activities. Every human activity is ultimately traceable to its worldview, and as such it is reducible to that worldview) Alparslan (1996: 6).

Ketiga definisi worldview di atas adalah definisi secara umum. Sementara Islam memiliki definisi yang memiliki nilai tambah karena sumbernya dan spektrumnya yang luas dan menyeluruh. Sebagai contoh akan disampaikan definisi worldview Islam oleh beberapa tokoh ulama zaman modern. Dalam tradisi Islam klasik terma khusus untuk pengertian worldview belum diketahui, meski tidak berarti Islam tidak memiliki worldview. Para ulama abad 20 menggunakan terma khusus untuk pengertian worldview ini, meskipun berbeda antara satu dengan yang lain. Al-Mawdudi mengistilahkannya dengan Islami Nazariyat (Islamic Vision), Sayyid Qutb menggunakan istilah al-Tasawwur al-Islami (Islamic Vision) , Atif alZayn menyebutkan Al Mabda' Al-Islami (Islamic Principle), al-Attas (1995: 2) menamakannya dengan Rukyatul Islam lil Wujud (Islamic Worldview). (Zarkasy: 2008:2)

Jika definisi-definisi tersebut digabungkan maka Islamic worldview adalah "Aqidah Fikriyah atau kepercayaan yang berdasarkan pada akal, yang asasnya 
adalah keesaan tauhid, yang terbentuk dalam pikiran dan hati setiap muslim dan berpengaruh terhadap pandangannya tentang keseluruhan aspek kehidupan"

M. Kamal Hasan menambahkan bahwa: “One's worldview is also refered to as one's philosophy, philosophy of life, mindset, outlook on life, conception of life, formula for life, ideology, faith, or even religion. It can be explicit or implicit, conscious or subconcious" (pandangan hidup seseorang juga disebut sebagai filsafat seseorang, filsafat kehidupan, pola pikir, pandangan hidup, konsepsi kehidupan, formula kehidupan, ideologi, iman, atau bahkan agama. Ini bisa eksplisit atau implisit, sadar atau bawah sadar).

Unsur-unsur worldview seseorang, ketika diperiksa secara filosofis atau mendalam, terkait dengan pelajaran berikut:

1. Ontologi : kepercayaan tentang sifat keberadaan, dan realitas pamungkas;

2. Teologi : kepercayaan tentang keberadaan dan sifat Allah;

3. Kosmologi : kepercayaan tentang asal usul dan sifat alam semesta, kehidupan, dan khususnya manusia;

4. Teleologi : kepercayaan tentang makna dan tujuan alam semesta, unsurunsurnya yang tidak hidup, dan penghuninya;

5. Epistomologi : kepercayaan tentang sifat dan sumber pengetahuan;

6. Antropologi : kepercayaan tentang sifat dan tujuan manusia secara umum dan diri sendiri secara khusus;

7. Aksiologi : kepercayaan tentang sifat nilai, apa yang baik dan buruk, apa yang benar dan yang salah (M. Kamal Hasan, 2017:1)

Meskipun istilah yang dipakai berbeda-beda pada umumnya para ulama tersebut sepakat bahwa Islam mempunyai cara pandangnya sendiri terhadap sesuatu. Penggunaan kata sifat Islam menunjukkan bahwa istilah ini sejatinya adalah netral. Artinya agama dan peradaban lain juga mempunyai worldview, vision atau $m a b d a^{\prime}$, sehingga $a l-M a b d a^{\prime}$ juga dapat dipakai untuk cara pandang komunis Al-Mabda' Al-Shuyu'i, Western worldview, Christian worldview, Hindu worldview, dan lain-lain. Maka dari itu ketika kata sifat Islam diletakkan di depan kata worldview, vision atau mabda', maka makna etimologis dan terminologis menjadi berubah. 


\section{B. Islamic Worldview Asas Lahirnya Tradisi Ilmiah}

Pikiran manusia dapat bekerja hanya dalam kesatuan konseptual atau meminjam istilah Kant sebagai " kesatuan arsitektonik", yang dalam pengertian umum disebut worldview. Ketika worldview diartikulasikan ke dalam skema konseptual yang canggih akan muncul di dalamnya struktur lain yang diselimuti oleh konsep pengetahuan doktrinal sebagai dasar epistemologis untu melakukan kegiatan pembelajaran. Ketika ini terjadi, para sarjana yang terlibat akan mengembangkan kosakata teknis dan bahasa khusus untuk kegiatan tersebut. Jaringan konsep-konsep ini dan kosakata yang muncul sebelum adanya ilmu yang kita sebut 'skema konseptual' (atau 'skema konseptual pra-ilmiah').

Jika struktur pengetahuan dalam worldview yang mendukung kegiatan intelektual dalam pengertian epistemologis, maka akan lahir definisi pengetahuan yang tidak hanya memberi penekanan pada konsep besar, tetapi juga menghasilkan dalam pikiran para anggota komuntas intelektual kerangka kerja umum dari teori engetahuan.

Ini berarti bahwa konsep utama yang menyediakan landasan epistemik dari setiap konseptual pra ilmiah, adalah konsep pengetahuan. Hal ini karena sains itu sendri pada dasarnya merupakan kegiatan pencarian pengetahuan; jika tidak ada dasar yang kuat untuk kegiatan pencarian pengetahuan, maka tidak akan pernah dapat muncul sebagai pendekatan disiplin yang menghasilkan sains.

Konsep pengetahuan kemudian menghasilkan konsep kebenaran, karena tujuan utama ilmu pengetahuan adalah pengetahuan sejati, yang pada gilirannya mengarah pada konsep metode, karena ilmuwan ingin mengetahui bagaimana pengetahuan sejati itu dicapai.

Oleh karena itu, pengetahuan, kebenaran dan metode adalah tiga konsep yang pada dasarnya saling berhubungan yang harus dikembangkan pertama sebagai landasan umum dalam struktur pengetahuan, dan sebagai istilah teknis mendasar dalam kosakata konseptual pra-ilmiah.

Nomenklatur ilmiah umum kemudian dikembangkan oleh para ilmuwan dan cendekiawan berdasarkan skema konseptual pra-ilmiah yang sudah ada, merupakan apa yang disebut 'skema konseptual ilmiah', dan dengan demikian termasuk dalam lima konsep dasar umum: pengetahuan, kebenaran , metode, teori dan sains. Ini adalah konsep umum yang telah dikembangkan oleh setiap tradisi 
ilmiah dalam sejarah; tetapi di samping konsep-konsep ilmiah doktrinal yang mendasar ini, setiap tradisi ilmiah berkembang dalam skema konseptual ilmiahnya. Sebaai contoh, dalam kasus Islam muncul konsep-konsep: 'ilm, ra'y, ijtihan, qiyas, fiqh,' aql, qalb, idrak, wahn , tadabbur, fikr, naar, Hikmah, yaqin, tafsir, ta'wil, kalm, nunaiq, 'ann, haqq, sidq, kidhb, wujud, 'adam, dahr, samad, sarmad, azal, abad, khalq, khulq, ikhtiyar, kisb, khayr, sharr, Hall, Haram , wajib, mumkin, amr, dan iradah.

Aktivitas ilmiah pada dasarnya adalah aktivitas kognitif dan karenanya harus diperiksa dari perspektif epistemologis, seperti yang telah kita lakukan di sini. Karena alasan ini pula, kegiatan semacam itu muncul terutama dari konstitusi pikiran manusia, yang bekerja dalam tiga kerangka kerja yang telah dibangunnya untuk dirinya sendiri. Dua kerangka kerja pertama telah diidentifikasi sebagai worldview dan skema konseptual ilmiah. Yang ketiga juga merupakan skema konseptual ilmiah tetapi yang digunakan dalam disiplin ilmu tertentu, dan karena itu juga dapat disebut 'skema konseptual ilmiah spesifik'. Skema ini muncul lebih tajam setelah setiap disiplin ilmu dinamai dan dengan demikian materi dan metodenya telah jelas didefinisikan. Proses epistemologis ini dapat dipahami melalui bagan sebagai berikut:

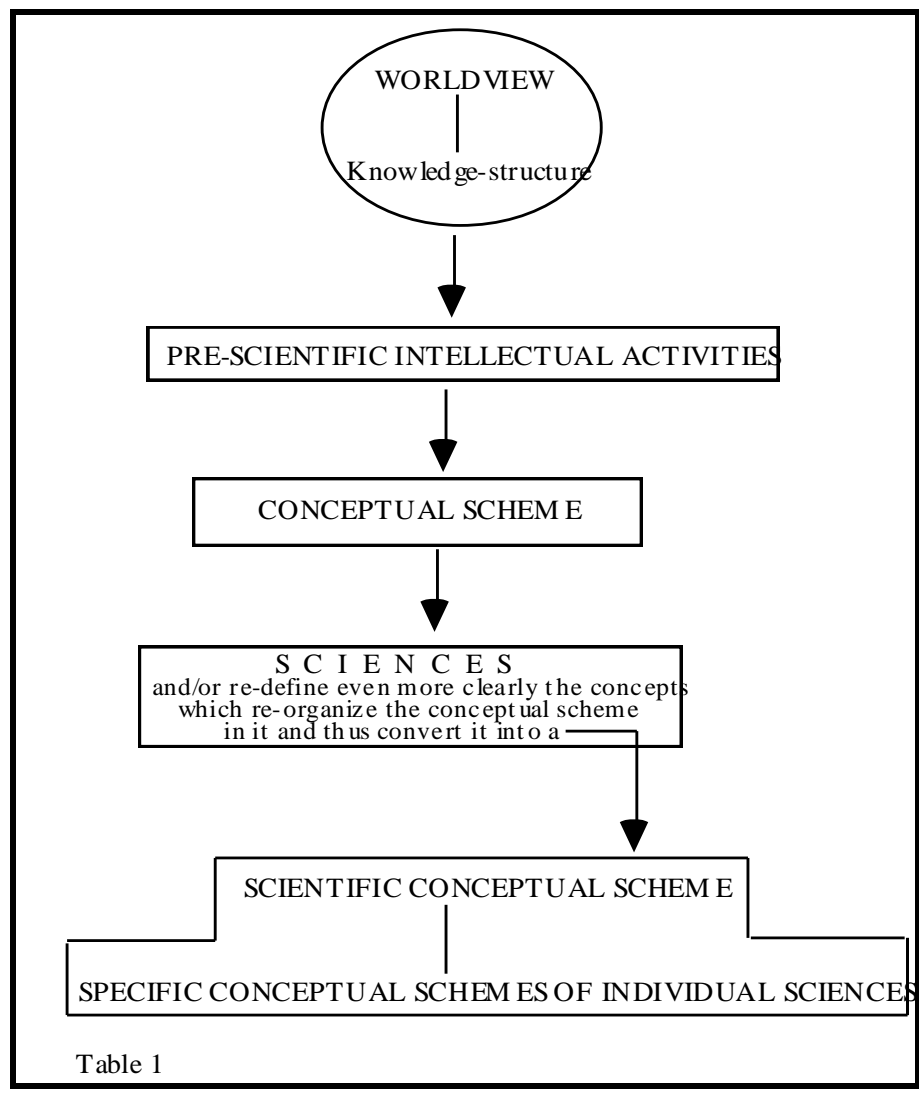

Sumber: Alparslan (n.d.) 
Skema konseptual ilmiah spesifik, sebagai kerangka kerja spesifik, termasuk nomenklatur ilmu tertentu. Tanpa nomenklatur seperti ini tidak akan ada sains yang bisa dikembangkan. Misalnya, jaringan istilah teknis dan konsep ilmiah yang digunakan dalam fisika Aristoteles merupakan kerangka spesifiknya. Skema konseptual ilmiah umum sebagai kerangka dalam fisika adalah jaringan konsep ilmiah dan cara mereka dikonseptualisasikan dalam tradisi ilmiah Yunani pada masanya; kerangka umum, sebagai worldview nya, adalah sistem Aristotelian. Sebagai contoh misalnya; kosakata teknis dan konsep-konsep teologis yang digunakan dalam ilmu kalam adalah skema konseptual ilmiah spesifik ilmu kalam; kosakata ilmiah umum yang digunakan dalam semua ilmu pengetahuan Islam adalah skema konseptual ilmiah sebagai kerangka kerja batin kalam; dan akhirnya worldview Islam adalah kerangka umum dari itu.

Berikutnya, ketika komunitas muslim yang baru menghadapi tantangan serius tertentu, ia dihadapkan pada dinamisme yang luar biasa dengan segala hal. Baik dalam tantangan spekulatif dari peradaban sebelumnya, terutama budaya jahiliyah, dan dorongan al-Qur'an untuk refleksi pada sifat manusia, tanggung jawab moral dan religiusnya sebagai khalifah di bumi dan di alam semesta, telah menyebabkan generasi awal muslim berspekulasi tentang berbagai masalah. Ketika mereka membahas pertanyaan-pertanyaan ini, nabi menerangi mereka di bawah bimbingan wahyu. Ini adalah proses pembangunan worldview Islam.

Oleh karena itu, sangat logis dikatakan bahwa, sejak awal, peradaban Islam didasarkan pada pemikiran rasional, yang dipandu oleh ajaran al-Qur'an; dan melalui atmosfer ini, generasi muslim awal mulai menjelaskan, melengkapi dan memikirkan kembali berbagai spekulatif. Kegiatan ilmiah dilakukan dalam tiga kerangka kerja mental : pertama adalah worldview ilmuan, yang merupakan lingkungan konseptual dimana kegiatan ilmiah diolah; kedua adalah komsepkonsep ilmiah yang terdefinisi dengan baik, yang disebut dengan 'konteks' (ilmu), atau lebih tepat disebut 'skema konseptual ilmiah (scientific conceptual scheme)' ; dan yang ketiga adalah jaringan kosakata teknis dan pandangan yang dihasilkan dari jaringan konsep dalam ilmu tertentu yang disebut dengan 'skema konseptual ilmiah spesifik'.

Skema konseptual ilmiah umum sebagai 'tradisi ilmiah' jika diwujudkan dalam peradaban tertentu akan mengambil nama peradaban tersebut. Hal ini 
karena tradisi pada dasarnya membutuhkan skema konseptual, yang dihasilkan oleh komunitas ulama. Jadi, tradisi ilmiah Islam pada dasarnya merupakan perwujudan dari skema konseptual ilmiah Islam yang wujud dalam peradaban Islam. Karena itu, skema ini terutama merupakan skema konseptual ilmiah umum dengan komunitasnya, tetapi karena sekema ini tidak dapat hidup tanpa ada lingkungan, maka tradisi ilmiah Islam harus mengasumsikan worldview Islam. Tradisi ilmiah Islam adalah konteks lingkungan Islam yang diturunkan dari satu generasi ilmuan ke yang berikutnya. Berikut penjelasan Alparslan Acikgenc:

After the prophet moved to Medina, he began setting up certain institution that became the model of education in later Islamic history. The school of the bench, known as Azhab Al-Suffah, or Ahl Al-Suffah (i. E; the people of the bench) is only one of these educational establishments which was founded by the prophet himself in Medina. Suffah was originally set a part for the lodging of new comers and those of the local people who were too poor to have a house of their ow. But soon it acquired the characterof a regular residential school whre reading, writing, muslim law, the memorizing of chapters of the qur'an, tajwid (how to recite the qurann correctly). And the other Islamic sciences were taught under the direct supervision of the prophet. 'ubadah ibn al-samit says that the prophet appointed him a teacher in the school of Suffah for classes in writing and in qur'anic studies. (Alparslan, n.d:21)

Maksud kutipan tersebut adalah: setelah nabi hijrah ke madinah, beliau mulai mendirikan lembaga-lembaga yang menjadi model pendidikan dari sejarah Islam di kemudain hari. Sekolah bangku , yang dikenal sebagai mazhab al-suffah atau ahl al-suffah (yaitu, rakyat bangku) adalah salah satu dari lembaga pendidikan yang didrikan oleh nabi sendiri di madinah. Suffah awalnya dikhususkan untuk tempat tinggal para pendatang baru dan orang-orang lokal yang terlalu miskin untuk memiliki rumah sendiri. Namun dalam perkembangannya ia memperoleh karakter sebagai pesantren tempat umat Islam belajar membaca, menulis, hukum Islam, menghafal bab-bab al quran, tajwid (cara membaca al-Qur'an dengan benar) dan ilmu-ilmu Islam lainnya diajarkan di bawah pengawasan langsung dari nabi. 'Ubadah ibn al-Samit mengatakan bahwa nabi mengangkatnya sebagai seorang guru di sekolah suffah untuk kelas-kelas penulisan dan studi al- Quran

Selain itu, ada cukup bukti bahwa suffah bukan satu-satunya sekolah di madinah. Ibn Hambal, misalnya mencatat bahwa pada waktu tertentu, "sekolompok 
70 siswa menghadiri ceramah seorang guru di madinah, dan bekerja di sana sampai pagi". Bahkan setidakya ada sembilan masjid di madinah pada masa nabi yang berfungsi sebagai sekolah

Orang-orang yang tinggal di daerah tersebut mengirim anak-anak mereka ke masjid-masjid lokal ini. Quba tidak jauh dari madinah. Nabi kadang-kadang pergi ke sana dan secara pribadi mengawasi sekolah di masjid tempat itu. Ada diktta umum nabi mengenai mereka yng belajar di sekolah-masjid. Dia juga memerintahkan orang untuk belajar dari tetangga mereka.

Di lembaga pendidikan pertama dalam Islam ini kandungan wahyu dan hadith-hadith Nabi dikaji dalam kegiatan belajar mengajar yang efektif. Tujuan utama AsÍÉb al-Øuffah adalah belajar dan mengamalkan Islam, seperti shalat, membaca al-Qur'an, memahami ayat-ayat bersama-sama, berzikir serta belajar menulis. Alumni, sebut saja begitu, dari sekolah masyarakat (learning society) ini juga menunjukkan kemampuan mereka dalam menghapal hadith-hadith Nabi. Lihat AbË Daud al-Sijistani, Sulayman ibn al-Asha'ath, (d.275 A.H) al-Sunan, 2 jilid (Egypt, Mustafa al-Babi al-Halabi, 1371) 2/237; and Ibn Majah, Muhammad Ibn Yazid (d.273), al-Sunan, dengan komentar dari Muhammad Fu'ad 'Abd al-BÉqÊ, (Kairo: DÉr IÍyÉ' al-Kutub al-'Arabiyyah, 1953, jilid 2, hal. 70)

Meski materinya masih sederhana tapi karena obyek kajiannya tetap berpusat pada wahyu, yang betul-betul luas dan kompleks. Materi kajiannya tidak dapat disamakan dengan materi diskusi spekulatif di Ionia, yang menurut orang Barat merupakan tempat kelahiran tradisi intelektual Yunani dan bahkan kebudayaan Barat (the cradle of western civilization). Yang jelas, AÎÍÉb al-Øuffah, adalah gambaran terbaik institusionalisasi kegiatan belajar-mengajar dalam Islam dan merupakan tonggak awal tradisi intelektual dalam Islam.

Kegiatan awal pengkajian wahyu dan hadith ini dilanjutkan oleh generasi berikutnya dalam bentuk yang lain. Dan tidak lebih dari dua abad lamanya telah muncul ilmuwan-ilmuwan terkenal dalam berbagai bidang studi keagamaan, seperti misalnya. Hasil dari kegiatan ini adalah munculnya, katakan, alumni-alumni yang menjadi pakar dalam hadith Nabi, seperti misalnya Abu Hurairah (hadith), Abu Dharr al-Ghiffari (hadith), Salman al-Farisi (hadith), 'Abdullah ibn Mas'ud (hadith), Ibnu Abbas (tafsir) Qadi Surayah (d.80/699), Muhammad ibn alHanafiyyah (d.81/700), (tasawuf) Hasan al-Basri (d.110/738), fiqih dan aqidah) 
Ghaylan al-Dimashqi (d.c.123/740), (aqidah) Ja'far al- Sadiq (d. 148/765), (aqidah dan fiqih) Abu Hanifah (d.150/767), (fiqih) Malik ibn Anas (179/796), (fiqih), Abu Yusuf (d.182/799), (fiqih), al-Shafi'i(204/819) (fiqih), dll. (Zarkasyi, 2008)

Fenomena sosial yang luar biasa ini, dipengaruhi oleh worldview Islam yang menghasilkan atmosfer akademik kondusif dalam melahirkan dan mengembangkan ilmu-ilmu keIslamana dan sains pada masa-masa selanjutnya.

\section{Penekanan Pada Konsep Ilmu}

Konsep 'ilm adalah konsep yang pertama-tama diperkenalkan sebagai elemen mendasar. Ilmu di dalam Islam mempunyai kedudukan yang istimewa, karena kehidupan manusia tidak akan tegak lurus tanpa ilmu. Ilmu merupakan sifat yang melekat pada para Nabi. Di antara rahmat Allah Subhanahu wa ta'ala yang diberikan kepada manusia adalah tidak mencabut ilmu dengan meninggalnya para nabi, karena para nabi mewariskan ilmu mereka kepada sekelompok manusia untuk menggantikan mereka dalam mengemban amanah Allah dalam mengajarkan manusia dan juga mengerjakan tugas-tugas para nabi ketika masih hidup, hanya saja kelompok tersebut tidak didukung oleh wahyu secara langsung dan juga mereka tidak ma'shum. Kelompok tersebut adalah para ulama.

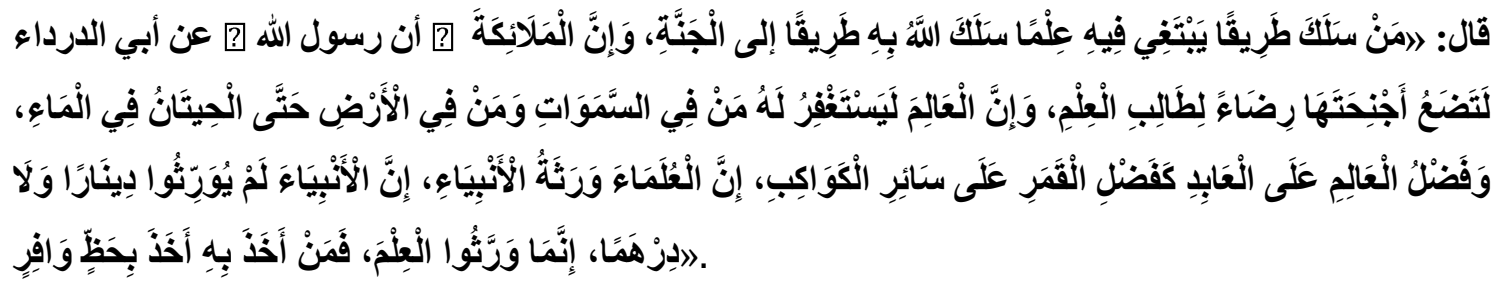

Artinya: “Dari Abu Darda' Radhiyallahu Anhu, bahwasannya Rasulullah Shallallahu 'Alaihi wa Sallam bersabda: "Barangsiapa melalui suatu jalan yang di dalamnya terdapat ilmu, maka Allah akan memberinya jalan menuju surga. Dan sungguh para malaikat meletakkan sayapnya bagi penuntut ilmu sebagai bentuk keridhaanya atas apa yang diperbuat, dan seluruh penduduk langit dan bumi meminta ampun bagi orang yang berilmu, bahkan ikan-ikan di air juga melakukan hal yang sama. Dan keutamaan ahli ilmu atas ahli ibadah seperti keutamaan bulan atas seluruh bintang, para ulama adalah orang yang mewarisi Nabi, dan para Nabi tidak mewariskan dinar ataupun dirham, mereka hanya mewariskan ilmu, maka barangsiapa mengambilnya maka ia telah mengambil bagian yang banyak," (al-Tirmidzi, Kitabul ilmi, Bab Fadlul Fiqhi alal Ibadah, No. 2682. Abu Dawud (2641), Ibnu Majah (223), 
Ahmad (21763), al-Darimi (342), Ibnu Hibban (88). Al-Albany berkata : shahih (6297)

Di akhir hadits Rasulullah Saw menjelaskan bahwa para nabi tidak mewariskan harta benda atau kekuasaan. Siapapun yang mengambil warisan tersebut, sungguh dia telah memperoleh keberuntungan. Allah berfirman :

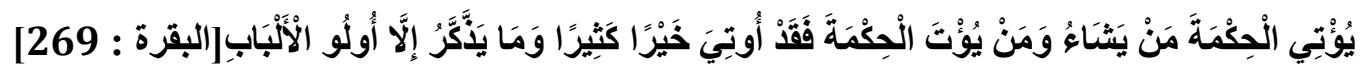
Artinya: "Allah menganugerahkan al- hikmah (kefahaman yang dalam tentang Al Quran dan As Sunnah) kepada siapa yang dikehendaki-Nya. Dan barangsiapa yang dianugerahi hikmah, ia benar-benar telah dianugerahi karunia yang banyak. Dan hanya orang-orang yang berakallah yang dapat mengambil pelajaran (dari firman Allah).

Di samping itu hadits di atas juga menjelaskan keutamaan ilmu dan kedudukan ulama, sampai-sampai para malaikat meletakkan sayapnya bagi penuntut ilmu bentuk ridha dan hormat. Rasulullah mengkhususkan ulama -bukan penuntut ilmu- dengan kedudukanyang khusus dengan menjelaskan bahwa makhluk yang ada di bumi dan langit memintakan ampun untuk seorang ulama, bahkan makhluk yang ada di aiar melakukan hal yang sama. Bukan hanya sebatas itu saja, beliau juga mengutamakan ulama daripada ahli ibadah, bahkan perbedaan keduanya sangat jauh dengan memberikan perbandingan antara bulan purnama dengan bintang, yang tentunya cahaya bulan purnama lebih terang benderang dari bintang-bintang walaupun jumlahnya lebih banyak.

Rasulullah di kesempatan lain membandingkan ulama dengan ahli ibadah seperti antara beliau dan orang yang kedudukannya paling rendah di kalangan kaum muslimin.

"Dari Abi Umamah al-Bahily bahwasannya disebutkan dua orang yang pertama ahli ibadah dan yang lainnya ulama, maka Rasulullah bersabda : "Keutamaan ulama atas ahli ibadah seperti antara kedudukanku dengan orang yang paling rendah diantara kalian." Lalu beliau bersabda : Sesungguhnya para malaikat, para penduduk langit dan bumi, para semut yang berada di liangnya, bahkan ikanpun turut mendoakan kebaikan kepada orang yang mengajarkan kebaikan kepada manusia. (HR. Tirmidzi).

Hadits tersebut menunjukkan kedudukan keistimewaan ulama dengan menjelaskan perbedaan yang sangat jauh antara ahli ibadah dengan ulama. 
Rasulullah tidak membandingkan dirinya dengan orang yang punya kedudukan di kalangan kaum muslimin, akan tetapi dengan orang yang paling rendah. Hal ini menunjukkan perbedaan yang jauh antara ulama dan ahli ibadah.

Mungkin ada yang bertanya-tanya, kenapa ulama lebih utama dari ahli ibadah? Pertanyaan tersebut terjawab ketika kita tahu bahwa Allah tanpa Ilmu maka dia bisa sesat bahkan bisa menyesatkan orag lain. Seperti halnyapenduduk mekkah di zaman rasulullah yang mengakui behwa mereka beribadah kepada allah tetapi tanpa ilmu, maka mereka tetap pada kekafiran dan kesesatan. Allah berfirman tentang perihal penyembahan mereka kepada berhala :

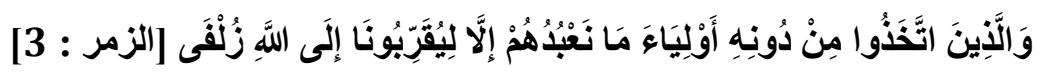

Artinya: "dan orang-orang yang mengambil pelindung selai Allah (berkata) : "kami tidak menyembah mereka meliaika supaya mereka medekatkan kami kepada Allah dengan sedekay-dekatnya" (QS. az -zumar : 3)

Imam al-Darimi menveritakan bahwasannya Umar bin Abdul Aziz pernah mengirim surat kepada penduduk madinah yang isinya : "sesungguhna orang yang beribadah tanpa ilmu maka dampak kerusakannya lebih banyak daripada kemaslahatannya."

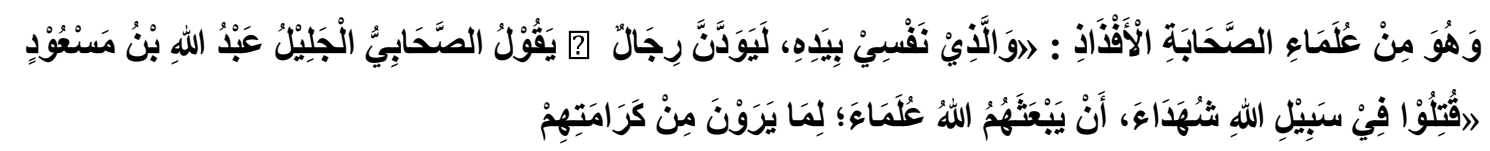

Abdullah bin Mas'ud bahkan menyatakan bahwa kedudukan ulama lebih utama daripada para mujahid, beliau berkata : "demi dzat yang jiwaku berada di tangannya, sesungguhnya orang yang mati syahid di jalan Allah mngharapkan agar Allah mengutus kepada mereka ulama karena mereka mengetahui keutamannya."

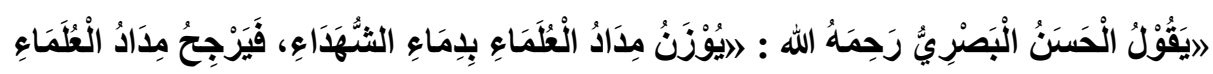

Hasan al Bashri berkata : "ketika tinta ulama ditimban dengan tinta syuhada", maka tinta ulama lebih unggul." ((al-Tirmidzi, Kitabul ilmi, Bab Fadlul Fiqhi alal Ibadah, No. 2682)

Mungkin sebagian orang menyangsikan pernyataan di atas. Hal ini bisa dijawab bahwa keutamaan jihad tidak diketahui kecuali dengan ilmu. Seseorang tidak berjihad kecuali dia tahu keutamaan berjhad. Syarat-syarat jihad tidak akan diketahui kecuali dengan ilmu. Ketentuan jihad yang fardhu'ain ataupun yang fardhu kifayah tidak akan diketahui kecuali dengan ilmu. Hal ini bisa menyebabkan orang yang tidak berilmu kadag meninggalkan yang fardhu dan melaksaakan yang 
sunnah dan ini merupakan hal yang tidak diperbolehkan. Begitu juga orang yang tidak berilmu bisa saja melampaui batas-batas jihad yang telah disyariatkan, seperti membunuh orang yang dilarang untuk dibunuh.

Jelaslah bahwa worldview Islam dimulai dengan penekanan besar pada konsep pengethuan. Pada saat itu istilah 'ilm dan fiqh digunakan secara khusus. Kedua istilah merujuk pada pengetahuan: yang pertama mengungkapkan pengetahuan yang tepat, dan pasti, sedangkan yang kedua menandakan, seperti yang akan kita tunjukan di bawah ini, ilmiah, dan karenanya pengetahuan tentang jenis rasional. Itulah sebabnya 'ilm digunakan oleh al quran untuk merujuk pada pengetahuan yang diwahyukan yang pasti dan absolut. Doa nabi untuk Ibnu Abbas menggunakan kedua istilah dalam konteks ini : "ya tuhan,beri dia pemahaman agama dan ajarkan dia dalam interpretasi". Karena jelas 'ilm digunakan untuk merujuk pada pengetahuan yang terungkap atau terkit dengan yang diungkapkan.

Kegiatan pendidikan dalam Islam awal menyebabkan munculnya sekelompok ulama (komunitas pra-ilmiah) yang mewariskan tradisi mengajar Nabi dan mencari pengetahuan kepada generasi ulama berikutnya yang menjadi murid mereka. Segera, ketika generasi baru sarjana mulai mengambil alih tradisi keilmuan ini, keinginan untuk belajar meningkat; sebagai hasilnya, sekelompok sarjana dengan mentalitas ilmiah yang canggih muncul. Sebagai hasil dari kegiatan belajar para cendekiawan ini segera muncul berbagai aliran pemikiran, seperti Sekolah Madura, Sekolah Kufah, Sekolah Basrah, dan juga sekolah-sekolah seperti Khorijiyyah, Qadariyyah, dll. Beberapa sekolah ini muncul sebagai akibat dari gejolak sosial-politik di dalam komuntas Muslim. Persis seperti peristiwa yang mengubah arah penyebab kontekstual dalam masyarakat tertentu. Harus diakui bahwa kekuatan sosial semacam itu yang dapat mempengaruhi jalannya proses ilmiah.

Melalui worldview Islam dari kelompok ilmuwan yang bekerja di bawah satu tradisi ilmiah yang memberi ilmu karakter sosial; kita akan mendefinisikan kelompok cendekiawan semacam itu yang merupakan satu kesatuan dalam pandangan dan skema konseptual ilmiah sebagai 'komunitas ilmiah', atau 'ulama' dalam tradisi ilmiah Islam. Karena itu, karakteristik komunitas ilmiah memiliki karakter berikut ini : 1. Tujuan metodologis; 2. Cita-cita ilmiah; 3. Hubungan formal; 4. Cita-cita marjinal. Tentu saja komunitas ilmiah tertentu akan memiliki 
karakteristik yag tidak dimiliki komunitas ilmiah lain, karena worldview Islam dan worldview para ilmuwan lainnya.

Komunitas ilmiah diperlukan untuk munculnya tradisi ilmiah. Bahkan, untuk keberadaan tradisi ilmiah, komunitas ilmiah diperlukan dengan sepanjang sejarah. Ketika kelompok ulama awal mulai bekerja pada isu-isu tertentu, mereka mengambil siswa yang tertarik dalam kegiatan pencarian pengetahuan. Dengan cara ini kounitas ilmuwan dibentuk sebagai hasil dari kegiatan pencarian pengetahuan yang mereka lakukan. Adalah mungkin untuk mengutip dua karakteristik yang dimiliki oleh kelompok cendekiawan yang tidak dimiliki oleh rekan mereka dari masyarakat yang sama; pertama adalah bahwa kelompok cendekiawan adalah mereka yang tertarik dalam pencarian pengetahuan; kedua, tetapi yang lebih penting adalah bahwa minat mereka dalam pencarian pengetahuan adalah dengan cara yang lebih sistematis dan metodis.

Keterkaitan formal sebagai karakteristik komunitas ilmiah didasarkan seperti yang lainnya berdasarkan susunan epistemologis fakultas pengetahuan kita. Misalnya, kita melakukan sains dengan cara kita belajar dari instruktur kita, sama seperti kita hidup di jalan saat kita belajar dari lingkungan kita termasuk orangtua kita dan lingkungan sosial. Karena hubungan formal juga merupakan elemen yang diperlukan dalam kebangkitan tradisi ilmiah, tidak ada komunitas ilmiah yang bisa menghindarinya. Pembentukan hubungan semacam itu membutuhkan sistem pengajaran yang terorganisasi dengan baik dan lembaga pendidikan.

Ada juga seperangkat karakteristik dasar yang muncul di sekitar kegiatan ilmiah, seperti karir ilmiah dan pendidikan harus terbaku unruk bakat, kegiatan ilmiah harus didukung tidak hanya secara finabsial, tetapi juga sosial dan politik. Semua prinsip ideal dari komunitas ilmiah yang sering disebut sebagai 'deal marginal'. Sama seperti cita-cita ilmiah, cita-cita marjinal juga bervariasi dari satu tradisi keilmuan.

Tradisi ilmiah Islam adalah manifestasi dari skema konseptual ilmiah Islam dalam lingkaran Islam. Skema konseptual ilmiah Islam, di sisi lain, skema konseptual Islam awal seperti yang diuraikan setelah munculnya ilmu-ilmu khusus. Dengan demikian sains dalam Islam pertama kali muncul dari skema konseptual. Tujuan dari paparan ini adalah untuk menunjukkan bahwa semua istilah teknis ini membentuk jaringan konsep yang canggih sampai akhir abad kedua Islam yang 
akhirnya mengarah pada munculnya ilmu-ilmu individu dalam tradisi pra ilmiah ini (sekitar tahun 800-an).

Kemudian dari kegiatan ilmiah ini muncul tradisi ilmiah Islam. Karena itu tidak hanya mencakup jaringan konseptual yang digunakan dalam kegiatan ilmiah, tetapi juga norma, praktik, instrumen pendidikan serta "seperangkat nilai-nilai budaya dan adat istiadat" yang diadopsi oleh kelompok ilmuwan yang terlibat dalam kegiatan ini. Kita dapat menunjukkan ini dengan memeriksa makna ilmiah yang secara bertahap melekat pada konsep yang terletak dalam skema konseptual Islam awal. Untuk melakukan ini, kita hanya akan memilih konsep yang paling mendasar dalam sains Islam, karena mereka berada dalam skema konseptual ilmiah Islam. Karena kita masih perlu melakukan lebih banyak penelitian historis untuk mengeluarkan bahan-bahan, kita tidak bisa membahas secara terperinci hal ini. Kami akan lebih berkonsentrasi pada istilah-istilah kunci tertentu saja, yang akan cukup membuktikan kasus kami dalam konteks ini, untuk menunjukkan kemunculan tradisi ilmiah Islam awal.

\section{SIMPULAN}

Bagaimana worldview Islam tumbuh dan berkembang dalam pikiran seseorang dan kemudian menjadi motor bagi perubahan 27ahasa umat Islam merupakan proses yang 27ahasa27. Secara historis tradisi intelektual dalam Islam diawali dari pemahaman terhadap al-Qur'an. Hal ini menandai lahirnya pandangan hidup Islam. Di dalam al-Qur'an terdapat konsep-konsep seminal yang kemudian dipahami, ditafsirkan dan dikembangkan oleh para sahabat, tabiin, tabi' tabiin dan para ulama sesudahnya. Konsep; ilm yang dalam al-Qur'an bersifat umum, dipamahi dan ditafsirakn oleh para ulama sehingga kemudian muncul beberapa definisi. Cikal bakal konsep ilmu pegetahuan dalam Islam adalah konsep-konsep kunci dalam wahyu yang ditafsirkan ke dalam berbagai aspek kehidupan dan pada akhirnya terakumulasi dalam bentuk peradaban. Jadi Islam adalah suatu peradaban yang lahir dan tumbuh berdasarkan wahyu yang didukung oleh tradisi intelektual. Tradisi intelektual dalam Islam juga memiliki media transformasi dalam bentuk institusi 27ahasa27olo yang dikenal dengan al-suffah dan komunitas 27ahasa27ology yang disebut Ashab al-Suffah.

Kegiatan keilmuan sebagaimana dijeaskan di atas secara 27ahasa27ology ada karena adanya pandangan dunia, yaitu pendangan dunia yang memiiki konsep-konsep 
yang canggih yang menjadi asas epitemologi untuk kegiatan ilmiah tersebut. Dengan konsep-konsep-konsep yang canggih tersebut para ilmuwan akhhirnya dapat mengembangkan istilah-istilah teknis dan 28ahasa khusus untuk itu. Bahkan konsep terebut berkembang menjadi struktur konsep keilmuan atau scientific conceptual scheme. Dari konspe ilmu pula kemudian muncul berbagai disiplin ilmu pengetahuan seperti, Ilmu Fiqih, Tafsir, Hadis, Kalam, Tasawuf, dan lain-lain.

\section{DAFTAR PUSTAKA}

al-Attas, SMN, in his Prolegomena to The Metaphysics of Islam An Exposition of the Fundamental Element of the Worldview of Islam, Kuala Lumpur, ISTAC, 1995

Al-Maududi, The Process of Islamic Revolution, Lahore, 1967.

Alparslan Acikgence, "The Framework for A history of Islamic Philosophy", Al-Shajarah, Journal of The International Institute of Islamic Thought and Civlization, Vol. 1, ISTAC, 1996

, The Emergence of Scientific Tradition in Islam, Department of Philosophy. Fatih University ISTANBUL, TURKEY, n.d.

Babak Ayazifar, "Intellect and Reason in the Islamic Worldview", http://thetech.mit.edu/V121/N51/col51babak.51c.html Published on Tuesday, October 16, 2001. Volume 121, Number 51

Hasan, Muhammad Kamal, "Worldview of Tawhid and It Implication on The Character and Reponsibility of Muslim Scholars and Intellectuals", Makalah Intellectual, Spiritual and Huan Knowledge Islamiazation, Unissula, Semarang, 2017

Smart, Ninian, Worldview, Crosscultural Explorations of Human Belief, Charles Sribner's sons, New York, n.d.

Tirmidzi, at, Kitabul ilmi, Bab Fadlul Fiqhi alal Ibadah, No. 2685. Al-Albany berkata : shahih (4213) di dalam Shahih Jami').

Wall, Thomas F, Thinking Critically About Philosophical Problem, A Modern Introduction, Wadsworth, Thomson Learning, Australia, 2001

Zarkasyi, Hamid Fahmy, Membangun Peradaban Islam, Kuliah Perdana, Seri Kuliah Peradaban Islam, Unissula, Semarang, 2008

-" Worldview Islam (Asas Islamisasi Ilmu Pengetahuan Kontemporer)”, Makalah Workshop Pengembangan Peradaban Islam, Unissula, 2009, 